\title{
Under Pressure: Climate Change, Upwelling, and Eastern Boundary Upwelling Ecosystems
}

\section{OPEN ACCESS}

Edited by:

Carlos M. Duarte,

King Abdullah University of Science and Technology, Saudi Arabia

Reviewed by:

Pengfei Lin,

Chinese Academy of Sciences, China

Yizhen $L i$,

Woods Hole Oceanographic

Institution, USA

*Correspondence:

Marisol García-Reyes

marisolgr@faralloninstitute.org

Specialty section:

This article was submitted to Global Change and the Future Ocean, a section of the journal

Frontiers in Marine Science

Received: 29 June 2015 Accepted: 23 November 2015 Published: 16 December 2015

Citation:

García-Reyes M, Sydeman WJ, Schoeman DS, Rykaczewski RR, Black BA, Smit AJ and Bograd SJ (2015) Under Pressure: Climate Change, Upwelling, and Eastern Boundary Upwelling Ecosystems.

Front. Mar. Sci. 2:109.

doi: 10.3389/fmars.2015.00109

\begin{abstract}
Marisol García-Reyes ${ }^{1 *}$, William J. Sydeman ${ }^{1}$, David S. Schoeman ${ }^{2}$, Ryan R. Rykaczewski ${ }^{3}$, Bryan A. Black ${ }^{4}$, Albertus J. Smit ${ }^{5}$ and Steven J. Bograd ${ }^{6}$

${ }^{1}$ Farallon Institute for Advanced Ecosystem Research, Petaluma, CA, USA, ${ }^{2}$ School of Science and Engineering, University of the Sunshine Coast, Maroochydore, QLD, Australia, ${ }^{3}$ Department of Biological Sciences and Marine Science Program, University of South Carolina, Columbia, SC, USA, ${ }^{4}$ Marine Science Institute, University of Texas at Austin, Port Aransas, TX, USA, ${ }^{5}$ Department for Biodiversity and Conservation Biology, University of the Western Cape, Bellville, South Africa,

${ }^{6}$ Environmental Research Division, National Oceanic and Atmospheric Administration Southwest Fisheries Science Center, Monterey, CA, USA
\end{abstract}

The IPCC AR5 provided an overview of the likely effects of climate change on Eastern Boundary Upwelling Systems (EBUS), stimulating increased interest in research examining the issue. We use these recent studies to develop a new synthesis describing climate change impacts on EBUS. We find that model and observational data suggest coastal upwelling-favorable winds in poleward portions of EBUS have intensified and will continue to do so in the future. Although evidence is weak in data that are presently available, future projections show that this pattern might be driven by changes in the positioning of the oceanic high-pressure systems rather than by deepening of the continental low-pressure systems, as previously proposed. There is low confidence regarding the future effects of climate change on coastal temperatures and biogeochemistry due to uncertainty in the countervailing responses to increasing upwelling and coastal warming, the latter of which could increase thermal stratification and render upwelling less effective in lifting nutrient-rich deep waters into the photic zone. Although predictions of ecosystem responses are uncertain, EBUS experience considerable natural variability and may be inherently resilient. However, multi-trophic level, end-to-end (i.e., "winds to whales") studies are needed to resolve the resilience of EBUS to climate change, especially their response to long-term trends or extremes that exceed pre-industrial ranges.

\footnotetext{
Keywords: upwelling intensification, stratification, upwelling drivers, climate change impacts, general circulation model projections
}

\section{INTRODUCTION}

Eastern Boundary Upwelling Systems (EBUS) are biologically productive marine regions covering $<1 \%$ of the ocean area, but providing up to $20 \%$ of the world's capture fisheries (Pauly and Christensen, 1995). These systems, embedded in the California, Humboldt, Canary/Iberian, and Benguela Currents (Table 1), provide ecosystem, economic, and recreational services to about 80 million people living along their coasts and in their immediate hinterlands. The high levels of productivity in the EBUS result from large-scale atmospheric pressure systems that favor alongshore, equatorward winds, which in combination with the Coriolis effect, advect surface water 
TABLE 1 | Eastern Boundary Upwelling Systems (EBUS).

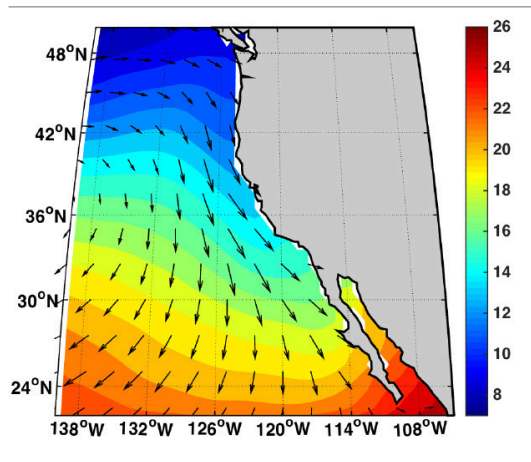

\section{California}

The California Current spans from central Baja California, Mexico, to central British Columbia, Canada Upwelling is more intense in central/northern California and highly seasonal off Oregon and Washington. This system experiences significant natural variability from such sources as the El Niño-Southern Oscillation (ENSO) and the Pacific Decadal Oscillation with important ecosystem consequences.

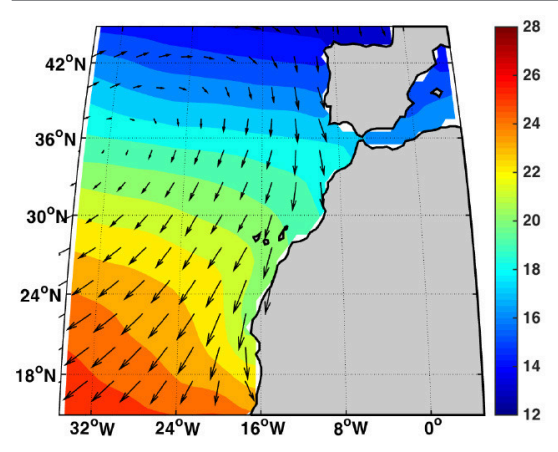

\section{Iberian/Canary}

The Iberian/Canary Current extends from the Iberian peninsula to West Africa, and is divided by the Gulf of Cadiz at the entrance to the Mediterranean Sea. The most intense and persistent upwelling is found off Northwest Africa. The Iberian section is heavily influenced by the North Atlantic Oscillation.

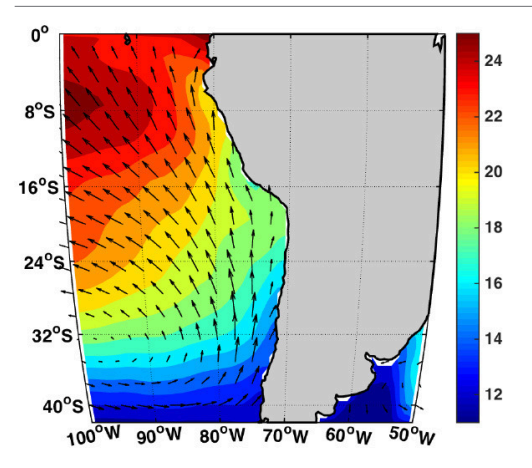

\section{Humboldt}

The Humboldt Current is the largest of the four EBUS, extending from the tip of the South American continent to the equator, where it connects with the equatorial current. Environmental and biological variability are heavily influenced by ENSO.

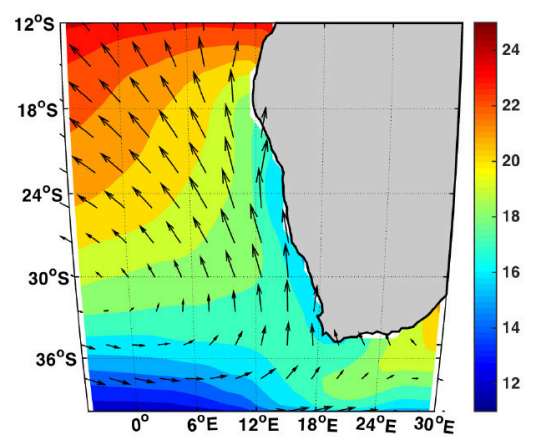

\section{Benguela}

The Benguela Current extends from the southeast tip of Africa to Angola. Upwelling is strongest and most persistent off Namibia in the Lüderitz region. Interannual variability in the physical and biological conditions relate to Benguela Niños and Pacific ENSO. In the south it is largely influenced by the variability in the Agulhas Current.

Maps show long-term means (1960-2014) of sea surface temperature (SST, ${ }^{\circ} \mathrm{C}$ ) and wind speed $(\mathrm{m} / \mathrm{s}$ ) and direction for summer months (June (December) in the northern (southern) hemisphere) around EBUS. SST is from the HadISST1 dataset (Rayner et al., 2003), and wind data are from the NCEP/NCAR reanalysis (Kalnay et al., 1996), which is generally congruent in mean wind velocity patterns with those from other sources (Kent et al., 2013).

offshore (Figure 1). Due to mass conservation, this advection causes deeper, cold, nutrient-rich waters with high $\mathrm{CO}_{2}$ concentrations, low $\mathrm{pH}$, and low oxygen concentrations to be upwelled from depth into the coastal photic zone (Huyer, 1983) where they fuel primary production in the form of phytoplankton blooms.

In embayments and other wind-protected inshore areas and in places where local circulation patterns may favor retention 

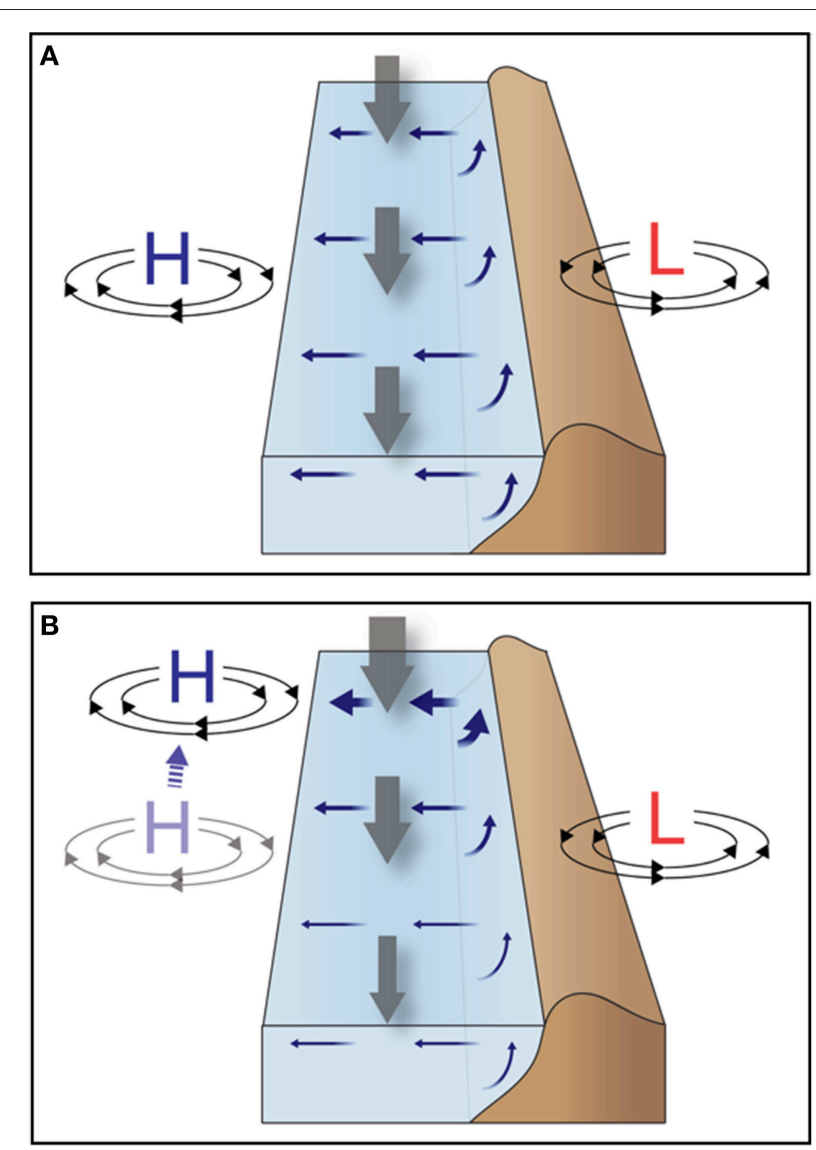

FIGURE 1 | Expected changes under climate change, from a Northern Hemisphere perspective. (A) Present: Pressure between ocean high- and land low-pressure systems drive upwelling-favorable winds (gray arrows) and thus upwelling (blue arrows). (B) Future: Poleward migration of ocean high-pressure systems, leading to enhanced (weakened) winds and upwelling in poleward (equatorward) regions of eastern boundary upwelling systems.

of local water masses, primary production can be intense and sustained (Graham and Largier, 1997). These "upwelling shadows" are sites of the highest chlorophyll concentrations in EBUS (Vander Woude et al., 2006), contrasting with lower productivity in areas with strong advection; this variability may influence zooplankton and higher trophic levels (Santora et al., 2011). Overall, the "bottom-up" drivers of nutrient enrichment, advection and retention, coupled with the transfer of carbon and energy up the food web make EBUS "hotspots" of productivity and upper-trophic-level biodiversity (Arístegui et al., 2009; Block et al., 2011), providing substantial economic value to coastal communities.

Because the mechanisms underpinning upwelling originate from large-scale atmospheric-oceanographic coupling, the amplitude and timing of upwelling-favorable winds are sensitive to climate variability (Montecinos et al., 2003; Macias et al., 2012), and are highly likely to be affected by global warming (Barros et al., 2014; Bakun et al., 2015). In particular, it is predicted that global warming will impact atmospheric pressure gradients and hence the coastal winds that cause upwelling
(Bakun, 1990; Bakun et al., 2015). Recent observations (Sydeman et al., 2014a) generally support this notion, and global model projections suggest intensification of regional coastal winds during the twenty-first century (Rykaczewski et al., 2015; Wang et al., 2015).

Understanding how these winds will change is of vital importance. For example, weaker upwelling may limit nutrient enrichment of the photic zone with potentially negative impacts on primary production (Chhak and Di Lorenzo, 2007). By contrast, stronger upwelling may increase nutrient input, but at the same time increase offshore transport (Cury and Roy, 1989; Botsford et al., 2006; Bakun et al., 2010, 2015). Other impacts include increased turbulence with increased winds (Cury and Roy, 1989; Yáñez et al., 2001) and changes in chemical mechanisms, e.g., ocean acidification and deoxygenation (Gruber, 2011; Doney et al., 2012), that may affect productivity.

Management of fisheries and other marine resources in EBUS could be improved by better understanding how nutrient enrichment and primary production are related to upwelling processes, and how they are likely to change in the future. While there have been a number of studies on this topic (Diffenbaugh et al., 2004; Di Lorenzo et al., 2005; Auad et al., 2006; Bakun et al., 2015), the Intergovernmental Panel on Climate Change 5th Assessment Report (IPCC AR5) has concluded that there is low confidence in projections regarding upwelling (Stocker et al., 2013; Barros et al., 2014). In part, this is a result of the substantial spatial heterogeneity in physical characteristics within EBUS, which emphasizes the role of local processes and resultant local biotic effects (Nelson and Hutchings, 1983; Dorman and Winant, 1995; Barton et al., 2013; Bakun et al., 2015). However, the low confidence in predictions regarding the ecological future of EBUS is driven more heavily by uncertainty surrounding the potentially counteracting effects of intensifying winds on the one hand, and increasing thermal stratification on the other. The former might lead to enhanced nutrient influx, while the latter could limit it (Di Lorenzo et al., 2005).

Even though the underlying complexity of upwellingecosystem relationships presents a challenge to forecasting, knowledge of EBUS is deep, as these systems have been extensively studied for nearly a century (Peña and Bograd, 2007), and there is a vast body of literature examining climatic impacts on upwelling as well as upwelling impacts on ecosystems. Given this context, and a spate of studies published while the IPCC AR5 was being prepared, we provide here a new synthesis of current research focused on the present and future impacts of climate change on coastal upwelling. We emphasize here the drivers of upwelling-favorable winds, the factors influencing nutrient enrichment, and potential changes in biogeochemistry.

\section{PRESSURE, WIND, AND UPWELLING IN A WARMING WORLD}

In EBUS, cross-shore atmospheric pressure gradients lead to alongshore, equatorward winds that drive coastal upwelling. Recognizing this, A. Bakun proposed that increasing global concentrations of greenhouse gasses would enhance 
warm-season upwelling (Bakun, 1990). The proposed mechanism was simple: air over land would warm more rapidly than air over the ocean, and resultant deepening of the continental thermal low-pressure systems (CTLPS) should increase the cross-shore pressure gradients that drive upwelling-favorable winds.

\section{Trends in Upwelling-Favorable Winds}

Several studies have focused on assessing trends in upwellingfavorable winds, and they found mixed results. The failure to reach consensus revolves largely around two related phenomena: (1) the small amplitude of unidirectional wind trends relative to amplitudes of seasonal, interannual, and decadal wind variability, and (2) the short duration of most observational time series relative to decadal variability. Further complications include (i) disparate data sets examined, (ii) inconsistencies in data treatment, including analyses of warm season vs. annual means as well as variable observation periods or quality and density of data, and (iii) changes in measurement techniques or models used to interpolate or reanalyze data (Cardone et al., 1990; Josey et al., 2002). Based on these differences, the IPCC AR5 (Stocker et al., 2013) concluded low confidence in common trends in upwelling-favorable winds.

A recent meta-analysis of published studies (Sydeman et al., 2014a), each with more than 20 years of observational or model-derived data, however, finds a more coherent pattern of intensifying upwelling-favorable winds in the Humboldt and the California Systems during the warm season. In the Benguela System, only annual data are available, but there, too, alongshore winds are intensifying. By contrast, in the Canary System, wind trends are equivocal, and even appear to be weakening in the Iberian region. Importantly, there is stronger agreement that significant trends of upwelling intensification are evident at higher latitude for all EBUS. Among studies excluded from the meta-analysis, either because they did not meet the strict selection criteria or because they were published after the analysis was completed, most (Di Lorenzo et al., 2005; Alves and Miranda, 2013; Barton et al., 2013; Bylhouwer et al., 2013; Stocker et al., 2013; Cropper et al., 2014; deCastro et al., 2014; Jacox et al., 2014; Sydeman et al., 2014b; Varela et al., 2015) show results consistent with the findings of Sydeman et al. (2014a). Those containing seemingly contradictory results (Demarcq, 2009; Dewitte et al., 2012) add uncertainty, but do not refute the findings of the metaanalysis, as they focus on local regions, use short time series and do not add uncertainty. Despite the fact that the meta-analysis by Sydeman et al. generally supports Bakun's proposition, we still cannot attribute coastal wind intensification in EBUS to global warming because we cannot discount the role of multi-decadal climate variability in the observed trends (Chhak and Di Lorenzo, 2007; Narayan et al., 2010; Pérez et al., 2010; Macias et al., 2012; Santos et al., 2012; Cropper et al., 2014; Jacox et al., 2014), nor is it a test of the Bakun hypothesis mechanism.

A gap in our understanding arises because the vast majority of studies focus on measures of central tendency (means or medians) in wind magnitude. Even though ecologically consequential changes in variance and phenology (timing of upwelling) have been observed in EBUS, studies examining trends in variance and timing remain rare. Such work is hindered by the complexities of the systems; the only generality that can be made is that upwelling-favorable winds tend to be most intense during the warm months of the year (Huyer, 1983; Nelson and Hutchings, 1983). Beyond this, however, the timing, intensity, and persistence of upwelling-favorable winds are remarkably variable within and among EBUS (Chavez and Messié, 2009). Of all EBUS, the most information on this subject is available from the California Current. In the central-northern portion of this system, upwelling winds primarily occur during the warm months of the year, while the seasonal range of pressure gradients in the southern portion of the system is reduced, and upwelling can occur there year-round. This pattern, however, is not static. Over recent decades, the timing of upwelling has trended toward later and shorter upwelling seasons in the northern portion of the California System and longer upwelling seasons in the southern portion (Bograd et al., 2009; García-Reyes and Largier, 2010). In contrast, a modeling study on wind stress curl (Diffenbaugh et al., 2004) found increased (decreased) upwelling in the late season in the northern (southern) California System.

Resolving these issues is important because variation in the timing of upwelling strongly influences ecosystem productivity. Years with early upwelling tend to be more productive at the upper trophic levels than those with later onset of upwelling (Black et al., 2011; García-Reyes et al., 2013b). Adding complexity to the picture, increases in the variability (extremes) of upwellingfavorable winds in the California Current have been observed since the late 1940s (Macias et al., 2012; García-Reyes et al., 2014), a finding consistent with increased upwelling-favorable winds during the warm months (Sydeman et al., 2014a). Less variability has been observed in the strength of upwelling winds through the year in the central Benguela and Canary Currents (Shannon and Nelson, 1996; Varela et al., 2015), though this conclusion might be influenced by a lack of studies. Clearly, further research is needed in all EBUS on changes in the timing and variability of upwelling given the influence these phenomena have on their ecosystems (Black et al., 2011; García-Reyes et al., 2014).

Wind projections from coupled atmosphere-ocean general circulation models (AOGCM) assembled for the IPCC AR5 have limited agreement that upwelling-favorable winds will intensify in response to climate change. Projections for the Humboldt (Garreaud and Falvey, 2009; Goubanova et al., 2011; Echevin et al., 2012; Belmadani et al., 2014; Rykaczewski et al., 2015; Wang et al., 2015), Benguela (Jury and Courtney, 1995; Rykaczewski et al., 2015; Wang et al., 2015), and Iberian Systems suggest future intensification of upwelling winds (Miranda et al., 2013; Casabella et al., 2014; Lopes et al., 2014; Rykaczewski et al., 2015; Wang et al., 2015). In contrast, the California System projections show non-significant or decreasing trends (Mote and Salathé, 2010; Rykaczewski et al., 2015; Wang et al., 2015). Furthermore, recent publications on wind trends based on global models reveal consistency in the spatial heterogeneity found by the meta-analysis, with increasing (decreasing) upwelling-favorable winds for poleward (equatorward) regions of EBUS (Rykaczewski et al., 2015; Wang et al., 2015). Note that these projections agree with observational records only in the Humboldt and Benguela Systems, though observational records corroborate that 
intensification trends are most likely in poleward regions of EBUS (Sydeman et al., 2014a).

The variability in trends derived from global-scale models may be due either to their relatively coarse resolution, which precludes adequate representation of smaller-scale coastal processes, including upwelling (Miranda et al., 2013; Casabella et al., 2014), or to their failure to adequately incorporate processes relevant to upwelling, e.g., cloud cover, inversion-layer height (Winant et al., 1988), or land-ocean pressure gradients. Downscaling global models to the coastal domain of EBUS is required to address some of these issues. Promising results from this type of approach have been obtained in the Humboldt System (Garreaud and Falvey, 2009; Belmadani et al., 2014).

\section{Drivers of Wind Intensification}

While Bakun's proposition of wind enhancement with global warming appears to be generally supported, the mechanism of change [intensification of CTLPS relative to the Ocean HighPressure System (OHPS)] may require revision. Wang et al. (2015) suggest support for this mechanism in their analyses of AOGCM outputs, but they did not examine the intensification of the CTLPS and consequent steepening of the cross-shore pressure gradient, key elements of the Bakun hypothesis. A more comprehensive analysis (Rykaczewski et al., 2015) of AOGCM output demonstrates that Bakun's mechanism breaks down at this crucial step: no deepening of the CTLPS occurs with increasing temperatures, except in the Canary Current System.

Changes in the structure of CTLPS seem intuitive under climate change. Nevertheless, the latitudinal differences in upwelling-favorable wind trends found in models (Rykaczewski et al., 2015; Wang et al., 2015) and in observations from recent decades (Sydeman et al., 2014a), in conjunction with evidence that winds in the EBUS are driven mainly by the magnitude and position of the OHPS (García-Reyes et al., 2013a; Schroeder et al., 2013), suggest that wind trends might be more sensitive to the poleward migration of the OHPS rather than changes in the CTLPS (Figure 1; Falvey and Garreaud, 2009; Belmadani et al., 2014; Bakun et al., 2015; Rykaczewski et al., 2015). Indeed, Rykaczewski et al. show that, in an ensemble of AOGCMs, the location of maximum upwelling along the EBUS coasts is correlated with the central latitude of the OHPS. Moreover, most AOGCMs show poleward expansion of the OHPS in the future (Diffenbaugh, 2005; Lu et al., 2007; Garreaud and Falvey, 2009; Echevin et al., 2012; Belmadani et al., 2014) caused by poleward expansion of the Hadley Cells in both hemispheres (Lu et al., 2007; Seager et al., 2010), and intensification of the OHPS in the northern hemisphere (Li et al., 2012). While one study using reanalysis data shows no evidence of trends in the position of mid-latitude atmospheric pressure centers over the past decades (Stocker et al., 2013), the prominent natural variability in the position of these systems over decadal time scales might mask potential trends (Bograd et al., 2009; Gutiérrez et al., 2011; Santos et al., 2012; Stocker et al., 2013). Understanding and predicting the intensity and position of OHPS is of great importance to the ecology of EBUS (Schroeder et al., 2013, 2014), making this area ripe for future analyses.

\section{WATER TEMPERATURES AND THE COUNTERACTING ROLES OF UPWELLING AND STRATIFICATION}

Global ocean temperatures have increased during the twentieth century and are expected to continue rising (probably at an accelerating rate) with climate change (Stocker et al., 2013). It is well known that coastal sea surface temperatures (SST) in EBUS are distinctively cooler than offshore regions at similar latitudes due to the nearshore upwelling of cold, nutrient-rich water. Moreover, global trends in SST may be counteracted by upwelling intensification in the poleward domains of the EBUS. Therefore, trends in coastal temperature in EBUS are expected to differ substantially from regional and global patterns of temperature change; indeed upwelling systems are viewed more generally as a source of significant bias in the global patterns of temperature change.

There is substantial but conflicting evidence on SST trends in EBUS (Mendelssohn and Schwing, 2002; Arístegui et al., 2009; Belkin, 2009; Demarcq, 2009; Lebassi et al., 2009; García-Reyes and Largier, 2010; Rouault et al., 2010; Gutiérrez et al., 2011; Seo et al., 2012; Barton et al., 2013; Barros et al., 2014; Sydeman et al., 2014b; Salvanes et al., 2015). Agreement among studies is low for two reasons: (1) the varying spatio-temporal resolutions of SST data capture different aspects of upwelling processes, and (2) trends are obscured by the interannual to multi-decadal variability that result from regional/local ocean and atmospheric processes. Different SST datasets also suggest different trends within and among EBUS, depending on resolution and other intrinsic factors (Belkin, 2009; Demarcq, 2009). In general, the coarse resolution of most SST datasets makes it difficult to separate nearshore upwelling-related temperatures (which could be decreasing due to upwelling intensification) from regional and eastern boundary current temperatures (which are likely to be increasing). Also, these data cannot resolve smallerscale advection or retention areas within EBUS, which could potentially have contrasting trends. Where high-resolution data have been analyzed, for example Lima and Wethey's (2012) analysis of daily AVHRR data at $0.25^{\circ}$ resolution, recent cooling trends are obvious for coastal areas in all but the Canary EBUS, especially at high latitudes and in summer months. There is, however, agreement among studies that coastal and offshore temperature trends differ. These studies exhibit decreasing or slowly increasing trends in nearshore SST, compared with increasing trends offshore in the Benguela (Rouault et al., 2010; Santos et al., 2012; Salvanes et al., 2015) and California systems (Mote and Salathé, 2010), a pattern consistent with observed increased upwelling-favorable winds (Sydeman et al., 2014a). When studying EBUS as units, given their spatial complexity, climate-change associated trends may be obscured by the counteracting effects of offshore warming and inshore cooling.

In general, regional ocean climate oscillations like the El NiñoSouthern Oscillation (ENSO) and Pacific Decadal Oscillation (PDO) for the California and Humboldt Current Systems, the Northern Atlantic Oscillation for the Canary/Iberian Current System, and Benguela Niño for the Benguela Current System 
(Minobe and Mantua, 1999; Lluch-Cota et al., 2001; Mendelssohn et al., 2003; Montecinos et al., 2003; Richter et al., 2010; Seo et al., 2012), impose considerable variability on temperatures and complicate attempts to assess long-term trends (Demarcq, 2009). Indeed, many of the observed trends in recent decades might be associated with these oscillations (Santos et al., 2012; Barton et al., 2013). Though predictions are controversial, some of these climate oscillations are expected to increase in amplitude or variance with climate change (Timmermann et al., 1999; Kuzmina et al., 2005; Sydeman et al., 2013; Cai et al., 2015), which would further mask monotonic trends.

AOGCM ensembles (Hoegh-Guldberg et al., 2014) show that modest rates of warming $\left(0.22-0.93^{\circ} \mathrm{C}\right.$ between 2010 and 2039) are expected within the four EBUS in the near-term, but the reliability of such projections is questionable, as AOGCMs do not represent upwelling adequately. In simulations of historical periods, large discrepancies between observed and predicted EBUS coast SST fields are found (Stock et al., 2011; Cambon et al., 2013), which could translate into biases in projected changes. However, coastal upwelling generally occurs within $50 \mathrm{~km}$ of the shore and these projected temperature changes might be more representative of the offshore portions of EBUS less influenced by upwelling. As with studies on wind fields, dynamic downscaling of AOGCMs might help in the resolution of these questions regarding future trends in coastal temperatures.

Warming of the ocean surface will, in time, propagate down through the water column and increase thermal stratification (Gruber, 2011). In upwelling systems, strong stratification limits the depth from which water is upwelled, and therefore the amount of nutrients brought to the euphotic zone (Chhak and Di Lorenzo, 2007; Jacox and Edwards, 2011; Jacox et al., 2015). Without alternative inputs from sources like rivers, the interplay between the intensity of upwelling winds and stratification determines the amount of nutrients entrained in the systems and thus strongly mediate biological productivity (McGowan et al., 1998; Di Lorenzo et al., 2005). On a global scale, stratification of the water-column between 0 and $200 \mathrm{~m}$ has increased by an estimated $4 \%$ during the period 1971 to 2010 as a result of climate change (Stocker et al., 2013). In the EBUS, however, stratification studies are sparse, as are associated observational data. In the central California Current EBUS, Palacios et al. (2004) estimated that stratification has increased since the 1950s in coastal and offshore areas. However, this change may reflect interdecadal variability (Bograd and Lynn, 2003; Chhak and Di Lorenzo, 2007), and its impacts on the nutrient input and consequent biological productivity have not been assessed except by theoretical modeling (Brochier et al., 2013; Schroeder et al., 2014). In other systems, similar studies are lacking due to the paucity of observational data on water-column temperature. At resolutions that capture the upwelling process, negative trends in nearshore SST seem to be consistent with increasing trends in upwelling-favorable winds (García-Reyes and Largier, 2010; Rouault et al., 2010; Lima and Wethey, 2012; Santos et al., 2012; Seo et al., 2012; deCastro et al., 2014). While not a measure of stratification, negative temperature trends suggest that the threshold at which stratification limits the nutrient content of upwelled water has not yet been reached, at least in some regions of the EBUS.

There is limited research on the future of stratification in EBUS under climate change, once again because AOGCMs fail to resolve upwelling adequately. Nevertheless, a modeling study by Brochier et al. (2013), based on downscaling of an AOGCM (Echevin et al., 2012), found that stratification might increase in the Humboldt Current under global climate change. In conjunction with negligible change in winds, their models showed limited nutrient input into the euphotic zone, which would negatively affect biological productivity. Ultimately, the ecological impacts of ocean warming and stratification might be ameliorated by increased upwelling-favorable winds combined with the innate resiliency of systems adapted to considerable intraseasonal to decadal temperature variability (Hare and Mantua, 2000; Santos et al., 2005). However, climate change impacts could still be important (Gruber, 2011), especially in regions where rising temperatures and decreasing upwelling cooccur.

\section{UPWELLING, STRATIFICATION AND BIOGEOCHEMISTRY}

Variability in the biogeochemical properties of upwelled waters will influence the ecology and productivity of EBUS. The deep waters brought toward the surface by upwelling are typically rich in nutrients and dissolved $\mathrm{CO}_{2}$, a consequence of the relatively long period where they have been isolated at depth from the euphotic zone and air-sea gas exchange (Feely et al., 2008). Below the euphotic zone, heterotrophic processes remineralize organic matter, consuming oxygen, and releasing $\mathrm{CO}_{2}$ in the process (Capone and Hutchins, 2013). Variability in the rate of upwelling associated with changes in local wind forcing, ventilation processes, or the source-water pathways that supply the EBUS have the potential to influence oxygen, nutrient, and $\mathrm{CO}_{2}$ concentrations in upwelled waters at the surface (Rykaczewski and Dunne, 2010).

Efforts to explore variability in source-water properties have been more intense in the California Current System than in any other EBUS. Here, decreased $\mathrm{pH}$ of shelf waters has been associated with strong upwelling at interannual scales (Feely et al., 2008), though longer-term data are generally not available. Over longer periods, decadal-scale changes in ventilation and source-water properties have likely resulted in decreased oxygen concentrations and shoaling of the oxygen minimum layer in the California (Bograd et al., 2008; McClatchie et al., 2010) and Benguela Systems (Monteiro et al., 2008; Salvanes et al., 2015). Such changes, however, have also been associated with known modes of decadal variability in oceanatmosphere processes (Deutsch et al., 2005; Chhak and Di Lorenzo, 2007).

Over centennial time scales, increased ocean stratification associated with surface warming may further reduce the ventilation of deep-water masses. As these water masses continue to be forced to the surface by the upwelling process, future decreases in oxygen concentration and $\mathrm{pH}$ and increases in 
nutrient concentration are expected (Rykaczewski and Dunne, 2010). While EBUS biotic systems might be resilient to changes in acidity and oxygen given their adaptations to naturally variable conditions (Capone and Hutchins, 2013), persistent changes in $\mathrm{pH}$ or oxygen may have important repercussions, such as displacement of suitable habitat (Hamukuaya et al., 1998; Grantham et al., 2004).

\section{SYNTHESIS}

There is robust observational evidence that upwelling-favorable winds have intensified in recent decades in some EBUS. Climate models also demonstrate, with high confidence, increasing (decreasing) trends in upwelling-favorable winds in the poleward (equatorward) regions of the EBUS. Recent decadal-scale trends in winds are consistent with predictions of the Bakun hypothesis of increasing upwelling with climate change. However, the mechanisms responsible for changes in winds are likely to be different. An alternative mechanism is that OHPS have migrated poleward and will continue to do so (Figure 1), as supported by a high level of agreement among different generations of global models. Reconciliation of this mechanism with a general lack of trends in strength and position of mid-latitude pressure systems in previous decades, which is almost certainly due to large degree of decadal-scale variability, will require further investigation.

There is low confidence regarding the future effects of climate change on coastal temperatures and biogeochemistry in the EBUS. This is partially due to the complexity of integrating global (climate change) and local (coastal upwelling) processes, but also due to the resolution, availability, and period of available data combined with the large degree of interannual to decadal variability in temperatures and biogeochemical properties. Most global climate models do not have the resolution to represent the upwelling process adequately; therefore the changes in physical and biogeochemical properties projected for the EBUS by the current generation of models are unlikely to be as accurate as those for other portions of the world's oceans. Downscaling of climate models shows promise in correcting this bias by including higher-resolution representation of winds and more accurately modeling relevant atmospheric and oceanic processes such as land- and ocean-air interactions, cloud formation, and oceanic mesoscale processes.

Owing to their inherent natural variability, it might be expected that EBUS will prove more resilient to climate change than other ocean ecosystems, but evidence of this resiliency is based more on these systems' abilities to recover from shortterm climate extremes. Much of our understanding of ecosystem responses to extremes stems from observations associated with ENSO (as well as PDO) in the California Current (Peterson and Schwing, 2003; Blamey et al., 2012; Sydeman et al., 2013; Black et al., 2014). How EBUS will respond to longterm changes in the mean magnitude of upwelling winds, stratification, and the biogeochemistry of source waters remains uncertain, as do interactive effects with natural interannual extremes, which could also change in behavior under climate change.

This lack of clear expectations for EBUS ecosystem properties is worrying because these regions are biologically rich, and thus highly relevant to society in terms of economics, conservation, and biodiversity. Given the uncertainties in present and future trends in the intensity and seasonality of upwelling, the paucity of studies on stratification, and the resultant effects on source-water characteristics, confidence in predicting biological

TABLE 2 | Observed and projected climate-change impacts on Eastern Boundary Upwelling Systems (EBUS).

\begin{tabular}{|c|c|c|c|}
\hline & Observed & Expected & Uncertainty \\
\hline $\begin{array}{l}\text { Large-scale drivers of } \\
\text { upwelling-favorable winds } \\
\text { Medium confidence }\end{array}$ & $\begin{array}{l}\text { No evidence of multi-decadal trends in } \\
\text { strength or position of pressure systems. }\end{array}$ & $\begin{array}{l}\text { Models suggest poleward migration } \\
\text { of ocean high-pressure systems, but } \\
\text { little to no change in intensity of the } \\
\text { thermal continental low-pressure } \\
\text { cells. }\end{array}$ & \\
\hline $\begin{array}{l}\text { Coastal temperature and stratification } \\
\text { Low confidence }\end{array}$ & $\begin{array}{l}\text { Complex integration of global (climate } \\
\text { change) and local (coastal upwelling) } \\
\text { processes. Differences in global and EBUS } \\
\text { SST trends are observed. }\end{array}$ & $\begin{array}{l}\text { Complex integration of global (climate } \\
\text { change) and local (coastal upwelling) } \\
\text { processes. } \\
\text { Ocean warming and stratification } \\
\text { might be ameliorated by increased } \\
\text { upwelling. }\end{array}$ & $\begin{array}{l}\text { Trends are sensitive to location } \\
\text { (nearshore vs. offshore), resolution, } \\
\text { period and dataset considered, as } \\
\text { well as to decadal variability. }\end{array}$ \\
\hline $\begin{array}{l}\text { Biogeochemistry } \\
\text { Low confidence }\end{array}$ & Decreased $\mathrm{pH}$ and oxygen concentration. & $\begin{array}{l}\text { Decreased } \mathrm{pH} \text { and oxygen } \\
\text { concentration, and increased nutrient } \\
\text { concentration. }\end{array}$ & $\begin{array}{l}\text { Uncertainty due to short period of } \\
\text { data availability. }\end{array}$ \\
\hline
\end{tabular}

These assessments are based on variable periods and datasets (see text and references). Confidence, based on amount of evidence and agreement among evidence, is noted in italics. 
impacts remains low. This synthesis (Table 2) highlights the need for comprehensive "winds to whales" studies that investigate consequences of present and future changes on various components of the upwelling process as well as the need to improve coupling between ecological and physical models.

\section{REFERENCES}

Alves, J. M. R., and Miranda, P. M. A. (2013). Variability of Iberian upwelling implied by ERA-40 and ERA-Interim reanalyses. Tellus A 65:19245. doi: 10.3402/tellusa.v65i0.19245

Arístegui, J., Barton, E. D., Alvarez-Salgado, X. A., Santos, A. M. P., Figueiras, F. G., Kifani, S., et al. (2009). Sub-regional ecosystem variability in the Canary Current upwelling. Prog. Oceanogr. 83, 33-48. doi: 10.1016/j.pocean.2009.07.031

Auad, G., Miller, A., and Di Lorenzo, E. (2006). Long-term forecast of oceanic conditions off California and their biological implications. J. Geophys. Res. 111, C9. doi: 10.1029/2005jc003219

Bakun, A. (1990). Global climate change and intensification of coastal ocean upwelling. Science 247, 198-201. doi: 10.1126/science.247.4939.198

Bakun, A., Black, B. A., Bograd, S. J., García-Reyes, M., Miller, A. J., Rykaczewski, R. R., et al. (2015). Anticipated effects of climate change on coastal upwelling ecosystems. Curr. Clim. Change Rep. 1, 85-93. doi: 10.1007/s40641-015-0008-4

Bakun, A., Field, D. B., Redondo-Rodriguez, A., and Weeks, S. J. (2010). Greenhouse gas, upwelling-favorable winds, and the future of coastal ocean upwelling ecosystems. Glob. Change Biol. 16, 1213-1228. doi: 10.1111/j.13652486.2009.02094.x

Barros, V. R., Field, C. B., Dokken, D. J., Mastrandrea, M. D., Mach, K. J., Bilir, T. E., et al. (eds.). (2014). Climate Change 2014: Impacts, Adaptation, and Vulnerability. Part B: Regional Aspects. Contribution of Working Group II to the Fifth Assessment Report of the Intergovernmental Panel on Climate Change. Cambridge; New York, NY: Cambridge University Press. 688.

Barton, E. D., Field, D. B., and Roy, C. (2013). Canary Current upwelling: more or less? Prog. Oceanogr. 116, 167-178. doi: 10.1016/j.pocean.2013.07.007

Belkin, I. M. (2009). Rapid warming of Large Marine Ecosystems. Prog. Oceanogr. 81, 207-213. doi: 10.1016/j.pocean.2009.04.011

Belmadani, A., Echevin, V., Codron, F., Takahashi, K., and Junquas, C. (2014). What dynamics drive future wind scenarios for coastal upwelling off Peru and Chile? Clim. Dynam. 43, 1893-1914. doi: 10.1007/s00382-013-2015-2

Black, B. A., Schroeder, I. D., Sydeman, W. J., Bograd, S. J., Wells, B. K., and Schwing, F. B. (2011). Winter and summer upwelling modes and their relevance to climate impacts and ecological response in the California Current Ecosystem. Glob. Change Biol. 17, 2536-2545. doi: 10.1111/j.1365-2486.2011.02422.x

Black, B. A., Sydeman, W. J., Frank, D. C., Griffin, D., Stahle, D. W., García-Reyes, M., et al. (2014). Six centuries of variability and extremes in a coupled marineterrestrial ecosystem. Science 345, 1498-1502. doi: 10.1126/science.1253209

Blamey, L. K., Howard, J. A. E., Agenbag, J., and Jarre, A. (2012). Regime-shifts in the southern Benguela shelf and inshore region. Prog. Oceanogr. 106, 80-95. doi: 10.1016/j.pocean.2012.07.001

Block, B. A., Jonsen, I. D., Jorgensen, S. J., Winship, A. J., Shaffer, S. A., Bograd, S. J., et al. (2011). Tracking apex marine predator movements in a dynamic ocean. Nature 475, 86-90. doi: 10.1038/nature10082

Bograd, S. J., and Lynn, R. J. (2003). Long-term variability in the southern California Current System. Deep-Sea Res. Pt. II 50, 2355-2370. doi: 10.1016/S0967-0645(03)00131-0

Bograd, S. J., Castro, C. G., Di Lorenzo, E., Palacios, D. M., Bailey, H., Gilly, W., et al. (2008). Oxygen declines and the shoaling of the hypoxic boundary in the California Current. Geophys. Res. Lett. 35, L12607. doi: 10.1029/2008GL034185

Bograd, S. J., Schroeder, I., Sarkar, N., Qiu, X., Sydeman, W. J., and Schwing, F. B. (2009). Phenology of coastal upwelling in the California Current. Geophys. Res. Lett. 36, L01602. doi: 10.1029/2008GL035933

Botsford, L. W., Lawrence, C. A., Dever, E. P., Hastings, A., and Largier, J. (2006). Effects of variable winds on biological productivity on continental

\section{ACKNOWLEDGMENTS}

We thank S. A. Thompson for editing, formatting, and referencing this paper. MGR, WS, RR, BB, and SB thank NSF for funding under grant OCE-1434732. MG and WS thank donors of the Farallon Institute. shelves in coastal upwelling systems. Deep-Sea Res. Pt. II 53, 3116-3140. doi: 10.1016/j.dsr2.2006.07.011

Brochier, T., Echevin, V., Tam, J., Chaigneau, A., Goubanova, K., and Bertrand, A. (2013). Climate change scenarios experiments predict a future reduction in small pelagic fish recruitment in the Humboldt Current system. Glob. Change Biol. 19, 1841-1853. doi: 10.1111/gcb.12184

Bylhouwer, B., Ianson, D., and Kohfeld, K. (2013). Changes in the onset and intensity of wind-driven upwelling and downwelling along the North American Pacific coast. J. Geophys. Res. 118, 2565-2580. doi: 10.1002/jgrc.20194

Cai, W., Wang, G., Santoso, A., McPhaden, M. J., Wu, L., Jin, F.-F., et al. (2015). Increased frequency of extreme La Nina events under greenhouse warming. Nat. Clim. Change 5, 132-137. doi: 10.1038/nclimate2492

Cambon, G., Goubanova, K., Marchesiello, P., Dewitte, B., Illig, S., and Echevin, V. (2013). Assessing the impact of downscaled winds on a regional ocean model simulation of the Humboldt system. Ocean Mod. 65, 11-24. doi: 10.1016/j.ocemod.2013.01.007

Capone, D. G., and Hutchins, D. A. (2013). Microbial biogeochemistry of coastal upwelling regimes in a changing ocean. Nat. Geosci. 6, 711-717. doi: 10.1038 /ngeo1916

Cardone, V. J., Greenwood, J. G., and Cane, M. A. (1990). On trends in historical marine wind data. J. Clim. 3, 113-127.

Casabella, N., Lorenzo, M. N., and Taboada, J. J. (2014). Trends of the Galician upwelling in the context of climate change. J. Sea Res. 93, 23-27. doi: 10.1016/j.seares.2014.01.013

Chavez, F. P., and Messié, M. (2009). A comparison of Eastern Boundary Upwelling Ecosystems. Prog. Oceanogr. 83, 80-96. doi: 10.1016/j.pocean.2009.07.032

Chhak, K., and Di Lorenzo, E. (2007). Decadal variations in the California Current upwelling cells. Geophys. Res. Lett. 34, L14604. doi: 10.1029/2007GL030203

Cropper, T. E., Hanna, E., and Bigg, G. R. (2014). Spatial and temporal seasonal trends in coastal upwelling off Northwest Africa, 1981-2012. Deep-Sea Res. Pt. I 86, 94-111. doi: 10.1016/j.dsr.2014.01.007

Cury, P., and Roy, C. (1989). Optimal environmental window and pelagic fish recruitment success in upwelling areas. Can. J. Fish. Aquat. Sci. 46, 670-680. doi: 10.1139/f89-086

deCastro, M., Gomez-Gesteira, M., Costoya, X., and Santos, F. (2014). Upwelling influence on the number of extreme hot SST days along the Canary upwelling ecosystem. J. Geophys. Res. 119, 3029-3040. doi: 10.1002/2013JC009745

Demarcq, H. (2009). Trends in primary production, sea surface temperature and wind in upwelling systems (1998-2007). Prog. Oceanogr. 83, 376-385. doi: 10.1016/j.pocean.2009.07.022

Deutsch, C., Emerson, S., and Thompson, L. (2005). Fingerprints of climate change in North Pacific oxygen. Geophys. Res. Lett. 32, L16604. doi: 10.1029/2005GL023190

Dewitte, B., Vazquez-Cuervo, J., Goubanova, K., Illig, S., Takahashi, K., Cambon, G., et al. (2012). Change in El Nino flavours over 1958-2008: implications for the long-term trend of the upwelling off Peru. Deep-Sea Res. Pt. II 77-80, 143-156. doi: 10.1016/j.dsr2.2012.04.011

Diffenbaugh, N. S. (2005). Response of large-scale eastern boundary current forcing in the 21st century. Geophys. Res. Lett. 32, L19718. doi: 10.1029/2005GL023905

Diffenbaugh, N. S., Snyder, M. A., and Sloan, L. C. (2004). Could CO2-induced land-cover feedbacks alter near-shore upwelling regimes? Proc. Nat. Acad. Sci. U.S.A. 101, 27-32. doi: 10.1073/pnas.0305746101

Di Lorenzo, E., Miller, A. J., Schneider, N., and McWilliams, J. C. (2005). The warming of the California current system: dynamics and ecosystem implications. J. Phys. Oceanogr. 35, 336-362. doi: 10.1175/JPO-2690.1 
Doney, S. C., Ruckelshaus, M., Duffy, J. E., Barry, J. P., Chan, F., English, C. A., et al. (2012). Climate change impacts on marine ecosystems. Ann. Rev. Mar. Sci. 4, 11-37. doi: 10.1146/annurev-marine-041911-111611

Dorman, C. E., and Winant, C. D. (1995). Buoy observations of the atmosphere along the west coast of the United States, 1981-1990. J. Geophys. Res. 100, 16029-16044. doi: 10.1029/95JC00964

Echevin, V., Goubanova, K., Belmadani, A., and Dewitte, B. (2012). Sensitivity of the Humboldt Current system to global warming: a downscaling experiment of the IPSL-CM4 model. Clim. Dyn. 38, 761-774. doi: 10.1007/s00382-0111085-2

Falvey, M., and Garreaud, R. D. (2009). Regional cooling in a warming world: recent temperature trends in the southeast Pacific and along the west coast of subtropical South America (1979-2006). J. Geophys. Res. 114, D04102. doi: 10.1029/2008jd010519

Feely, R. A., Sabine, C. L., Hernandez-Ayon, J. M., Ianson, D., and Hales, B. (2008). Evidence for upwelling of corrosive "acidified" water onto the continental shelf. Science 320, 1490-1492. doi: 10.1126/science. 1155676

García-Reyes, M., and Largier, J. (2010). Observations of increased wind-driven coastal upwelling off central California. J. Geophys. Res. 115, C04011. doi: $10.1029 / 2009 j \mathrm{jc} 005576$

García-Reyes, M., Largier, J. L., and Sydeman, W. J. (2014). Synoptic-scale upwelling indices and predictions of phyto- and zooplankton populations. Prog. Oceanogr. 120, 177-188. doi: 10.1016/j.pocean.2013.08.004

García-Reyes, M., Sydeman, W. J., Black, B. A., Rykaczewski, R. R., Schoeman, D. S., Thompson, S. A., et al. (2013a). Relative influence of oceanic and terrestrial pressure systems in driving upwelling-favorable winds. Geophys. Res. Lett. 40, 5311-5315. doi: 10.1002/2013GL057729

García-Reyes, M., Sydeman, W. J., Thompson, S. A., Black, B. A., Rykaczewski, R. R., Thayer, J. A., et al. (2013b). Integrated assessment of wind effects on Central California's pelagic ecosystem. Ecosystems 16, 722-735. doi: 10.1007/s10021013-9643-6

Garreaud, R. D., and Falvey, M. (2009). The coastal winds off western subtropical South America in future climate scenarios. Int. J. Clim. 29, 543-554. doi: $10.1002 /$ joc. 1716

Goubanova, K., Echevin, V., Dewitte, B., Codron, F., Takahashi, K., Terray, P., et al. (2011). Statistical downscaling of sea-surface wind over the PeruChile upwelling region: diagnosing the impact of climate change from the IPSL-CM4 model. Clim. Dyn. 36, 1365-1378. doi: 10.1007/s00382-0100824-0

Graham, W. M., and Largier, J. L. (1997). Upwelling shadows as nearshore retention sites: the example of northern Monterey Bay. Cont. Shelf Res. 17, 509-532. doi: 10.1016/S0278-4343(96)00045-3

Grantham, B. A., Chan, F., Nielsen, K. J., Fox, D. S., Barth, J. A., Huyer, A., et al. (2004). Upwelling-driven nearshore hypoxia signals ecosystem and oceanographic changes in the northeast Pacific. Nature 429, 749-754. doi: 10.1038 /nature02605

Gruber, N. (2011). Warming up, turning sour, losing breath: ocean biogeochemistry under global change. Phil. Trans. R. Soc. A 369, 1980-1996. doi: 10.1098/rsta.2011.0003

Gutiérrez, D., Bouloubassi, I., Sifeddine, A., Purca, S., Goubanova, K., Graco, M., et al. (2011). Coastal cooling and increased productivity in the main upwelling zone off Peru since the mid-twentieth century. Geophys. Res. Lett. 38, L07603. doi: 10.1029/2010GL046324

Hamukuaya, H., O’Toole, M. J., and Woodhead, P. M. J. (1998). Observations of severe hypoxia and offshore displacement of Cape hake over the Namibian shelf in 1994. S. Afr. J. Mar. Sci. 19, 57-59. doi: 10.2989/025776198784126809

Hare, S. R., and Mantua, N. J. (2000). Empirical evidence for North Pacific regime shifts in 1977 and 1989. Prog. Oceanogr. 47, 103-145. doi: 10.1016/S00796611(00)00033-1

Hoegh-Guldberg, O., Cai, R., Poloczanska, E. S., Brewer, P. G., Sundby, S., Hilmi, K., et al. (2014). "The ocean-supplementary material," in Climate Change 2014: Impacts, adaptation, and vulnerability. Part B: Regional aspects. Contribution of Working Group II to the Fifth Assessment Report of the Intergovernmental Panel on Climate Change, eds V. R. Barros, C. B. Field, D. J. Dokken, M. D. Mastrandrea, K. J. Mach, T. E. Bilir, et al. (Cambridge; New York, NY: Cambridge University Press), SM30-6.

Huyer, A. (1983). Coastal upwelling in the California Current System. Prog. Oceanogr. 12, 259-284. doi: 10.1016/0079-6611(83)90010-1
Jacox, M. G., Bograd, S. J. Hazen, E. L., and Fiechter, J. (2015). Sensitivity of the California Current nutrient supply to wind, heat, and remote ocean forcing. Geophys. Res. Lett. 42, 5950-5957. doi: 10.1002/2015gl065147

Jacox, M. G., and Edwards, C. A. (2011). Effects of stratification and shelf slope on nutrient supply in coastal upwelling regions. J. Geophys. Res. 116, C03019. doi: 10.1029/2010jc006547

Jacox, M. G., Moore, A. M., Edwards, C. A., and Fiechter, J. (2014). Spatially resolved upwelling in the California Current System and its connections to climate variability. Geophys. Res. Lett. 41, 3189-3196. doi: 10.1002/2014GL059589

Josey, S. A., Kent, E. C., and Taylor, P. K. (2002). Wind stress forcing of the ocean in the SOC climatology: comparisons with the NCEP-NCAR, ECMWF, UWM/COADS, and Hellerman and Rosenstein Datasets. J. Phys. Oceanogr. 32, 1993-2019. doi: 10.1175/1520-0485(2002)032<1993:WSFOTO > 2.0.CO;2

Jury, M. R., and Courtney, S. (1995). Climatic determinants of Benguela SST variability. Cont. Shelf Res. 15, 1339-1354. doi: 10.1016/0278-4343(94)00090-A

Kalnay, E., Kanamitsu, M., Kistler, R., Collins, W., Deaven, D., Gandin, L., et al. (1996). The NCEP/NCAR 40-year reanalysis project. Bull. Amer. Meteorol. Soc. 77, 437-471.

Kent, E. C., Fangohr, S., and Berry, D. I. (2013). A comparative assessment of monthly mean wind speed products over the global ocean. Inter. J. Climatol. 33, 2520-2541. doi: 10.1002/joc.3606

Kuzmina, S. I., Bengtsson, L., Johannessen, O. M., Drange, H., Bobylev, L. P., and Miles, M. W. (2005). The North Atlantic Oscillation and greenhouse-gas forcing. Geophys. Res. Lett. 32, L04703. doi: 10.1029/2004GL021064

Lebassi, B., Gonzalez, J., Fabris, D., Maurer, E., Miller, N., Milesi, C., et al. (2009). Observed 1970-2005 cooling of summer daytime temperatures in coastal California. J. Clim. 22, 3558-3573. doi: 10.1175/2008JCLI2111.1

Li, W., Li, L., Ting, M., and Liu, Y. (2012). Intensification of Northern Hemisphere subtropical highs in a warming climate. Nat. Geo. 5, 830-834. doi: 10.1038/ngeo1590

Lima, F. P., and Wethey, D. S. (2012). Three decades of high-resolution coastal sea surface temperatures reveal more than warming. Nat. Comm. 3, 704. doi: $10.1038 /$ ncomms 1713

Lluch-Cota, D. B., Wooster, W. S., and Hare, S. R. (2001). Sea surface temperature variability in coastal areas of the Northeastern Pacific related to the El NinoSouthern Oscillation and the Pacific Decadal Oscillation. Geophys. Res. Lett. 28, 2029-2032. doi: 10.1029/2000GL012429

Lopes, J. F., Ferreira, J. A., Cardoso, A. C., and Rocha, A. C. (2014). Variability of temperature and chlorophyll of the Iberian Peninsula near costal ecosystem during an upwelling event for the present climate and a future climate scenario. J. Mar. Sys. 129, 271-288. doi: 10.1016/j.jmarsys.2013.07.002

Lu, J., Vecchi, G. A., and Reichler, T. (2007). Expansion of the Hadley cell under global warming. Geophys. Res. Lett. 34, L06805. doi: 10.1029/2006GL028443

Macias, D., Landry, M. R., Gershunov, A., Miller, A. J., and Franks, P. J. S. (2012). Climatic control of upwelling variability along the western North American coast. PLoS ONE 7:e30436. doi: 10.1371/journal.pone.0030436

McClatchie, S., Goericke, R., Cosgrove, R., Auad, G., and Vetter, R. (2010). Oxygen in the Southern California Bight: multidecadal trends and implications for demersal fisheries. Geophys. Res. Lett. 37, L19602. doi: 10.1029/2010GL044497

McGowan, J. A., Cayan, D. R., and Dorman, L. M. (1998). Climate-ocean variability and ecosystem response in the Northeast Pacific. Science 281, 210-217. doi: $10.1126 /$ science. 281.5374 .210

Mendelssohn, R., and Schwing, F. B. (2002). Common and uncommon trends in SST and wind stress in the California and Peru-Chile Current Systems. Prog. Oceanogr. 53, 141-162. doi: 10.1016/S0079-6611(02)00028-9

Mendelssohn, R., Schwing, F. B., and Bograd, S. J. (2003). Spatial structure of subsurface temperature variability in the California Current, 1950-1993. J. Geophys. Res. 108, 3093. doi: 10.1029/2002JC001568

Minobe, S., and Mantua, N. (1999). Interdecadal modulation of interannual atmospheric and oceanic variability over the North Pacific. Prog. Oceanogr. 43, 163-192. doi: 10.1016/S0079-6611(99)00008-7

Miranda, P. M. A., Alves, J. M. R., and Serra, N. (2013). Climate change and upwelling: response of Iberian upwelling to atmospheric forcing in a regional climate scenario. Clim. Dyn. 40, 2813-2824. doi: 10.1007/s00382-012-1442-9

Montecinos, A., Purca, S., and Pizarro, O. (2003). Interannual-to-interdecadal sea surface temperature variability along the western coast of South America. Geophys. Res. Lett. 30, 1570. doi: 10.1029/2003GL017345 
Monteiro, P. M. S., Van Der Plas, A. K., Melice, J.-L., and Florenchie, P. (2008). Interannual hypoxia variability in a coastal upwelling system: ocean-shelf exchange, climate and ecosystem-state implications. Deep-Sea Res. Pt. I 55, 435-450. doi: 10.1016/j.dsr.2007.12.010

Mote, P. W., and Salathé, E. P. J. (2010). Future climate change in the Pacific Northwest. Clim. Change 102, 29-50. doi: 10.1007/s10584-010-9848-Z

Narayan, N., Paul, A., Mulitza, S., and Schulz, M. (2010). Trends in coastal upwelling intensity during the late 20th century. Ocean Sci. 6, 815-823. doi: 10.5194/os-6-815-2010

Nelson, G., and Hutchings, L. (1983). The Benguela upwelling area. Prog. Oceanogr. 12, 333-356. doi: 10.1016/0079-6611(83)90013-7

Palacios, D. M., Bograd, S. J., Mendelssohn, R., and Schwing, F. B. (2004). Longterm and seasonal trends in stratification in the California Current, 1950-1993. J. Geophys. Res. 109, C10016. doi: 10.1029/2004JC002380

Pauly, D., and Christensen, V. (1995). Primary production required to sustain global fisheries. Nature 374, 255-257. doi: 10.1038/374255a0

Peña, M. A., and Bograd, S. J. (2007). Time series of the northeast Pacific. Prog. Oceanogr. 75, 115-119. doi: 10.1016/j.pocean.2007.08.008

Pérez, F. F., Padin, X. A., Pazos, Y., Gilcoto, M., Cabanas, M., Pardo, P. C., et al. (2010). Plankton response to weakening of the Iberian coastal upwelling. Glob. Change Biol. 16, 1258-1267. doi: 10.1111/j.1365-2486.2009.02125.x

Peterson, W. T., and Schwing, F. B. (2003). A new climate regime in Northeast Pacific ecosystems. Geophys. Res. Lett. 30, 1896. doi: 10.1029/2003GL017528

Rayner, N. A., Parker, D. E., Horton, E. B.;, Folland, C. K., Alexander, L. V., Rowell, D. P., et al. (2003). Global analyses of sea surface temperature, sea ice, and night marine air temperature since the late nineteenth century J. Geophys. Res. 108, 4407. doi: 10.1029/2002jd002670

Richter, I., Behera, S. K., Masumoto, Y., Taguchi, B., Komori, N., and Yamagata, T. (2010). On the triggering of Benguela Ninos: remote equatorial versus local influences. Geophys. Res. Lett. 37, L20604. doi: 10.1029/2010GL044461

Rouault, M., Pohl, B., and Penven, P. (2010). Coastal oceanic climate change and variability from 1982 to 2009 around South Africa. Afr. J. Mar. Sci. 32, 237-246. doi: 10.2989/1814232X.2010.501563

Rykaczewski, R. R., and Dunne, J. P. (2010). Enhanced nutrient supply to the California Current Ecosystem with global warming and increased stratification in an earth system model. Geophys. Res. Lett. 37, L21606. doi: 10.1029/2010GL045019

Rykaczewski, R. R., Dunne, J. P., Sydeman, W. J., García-Reyes, M., Black, B. A., and Bograd, S. J. (2015). Poleward intensification of coastal upwelling in response to global warming. Geophys. Res. Lett. 42, 6424-6431. doi: 10.1002/2015GL064694

Salvanes, A. G. V., Bartholomae, C., Yemane, D., Gibbons, M. J., Kainge, P., Krakstad, J.-O., et al. (2015). Spatial dynamics of the bearded goby and its key fish predators off Namibia vary with climate and oxygen availability. Fish. Oceanogr. 24, 88-101. doi: 10.1111/fog. 12068

Santora, J. A., Ralston, S., and Sydeman, W. J. (2011). Spatial organization of krill and seabirds in the central California Current. ICES J. Mar. Sci. 68, 1391-1402. doi: 10.1093/icesjms/fsr046

Santos, A. M. P., Kazmin, A. S., and Peliz, A. J. (2005). Decadal scales in the Canary Upwelling System as revealed by satellite observations: their impact on productivity. J. Mar. Res. 63, 359-379. doi: 10.1357/0022240053693671

Santos, F., Gomez-Gesteira, M., De Castro, M., and Alvarez, I. (2012). Differences in coastal and oceanic SST trends due to the strengthening of coastal upwelling along the Benguela current system. Cont. Shelf Res. 34, 79-86. doi: 10.1016/j.csr.2011.12.004

Schroeder, I. D., Black, B. A., Sydeman, W. J., Bograd, S. J., Hazen, E. L., Santora, J. A., et al. (2013). The North Pacific High and wintertime pre-conditioning of California Current productivity. Geophys. Res. Lett. 40, 541-546. doi: $10.1002 /$ grl.50100

Schroeder, I. D., Santora, J. A., Moore, A. M., Edwards, C. A., Fiechter, J., Hazen, E. L., et al. (2014). Application of a data-assimilative regional ocean modeling system for assessing California Current System ocean conditions, krill, and juvenile rockfish interannual variability. Geophys. Res. Lett. 41, 5942-5950. doi: 10.1002/2014GL061045

Seager, R., Naik, N., and Vecchi, G. A. (2010). Thermodynamic and dynamic mechanisms for large-scale changes in the hydrological cycle in response to global warming. J. Clim. 23, 4651-4668. doi: 10.1175/2010JCLI3655.1

Seo, H., Brink, K. H., Dorman, C. E., Koracin, D., and Edwards, C. A. (2012). What determines the spatial pattern in summer upwelling trends on the U.S. West Coast? J. Geophys. Res. 117, C08012. doi: 10.1029/2012JC008016

Shannon, L. V., and Nelson, G. (1996). "The Benguela: large scale features and processes and system variability," in The South Atlantic: Present and Past Circulation, eds G. Wefer, W. H. Berger, G. Siedler, and D. J. Webb (Berlin; Heidelberg: Springer-Verlag), 163-210.

Stock, C. A., Alexander, M. A., Bond, N. A., Brander, K. M., Cheung, W. W. L., Curchitser, E. N., et al. (2011). On the use of IPCC-class models to assess the impact of climate on Living Marine Resources. Prog. Oceanogr. 88, 1-27. doi: 10.1016/j.pocean.2010.09.001

Stocker, T. F., Qin, D., Plattner, G.-K., Tignor, M., Allen, S. K., Boschung, J., et al. (eds.). (2013). IPCC AR5: Climate Change: The Physical Science Basis. Cambridge; New York, NY: Cambridge University Press.

Sydeman, W. J., García-Reyes, M., Schoeman, D., Rykaczewski, R. R., Thompson, S. A., Black, B. A., et al. (2014a). Climate change and wind intensification in coastal upwelling ecosystems. Science 345, 77-80. doi: 10.1126/science.1251635

Sydeman, W. J., Santora, J. A., Thompson, S. A., Marinovic, B., and Di Lorenzo, E. (2013). Increasing variance in North Pacific climate relates to unprecedented ecosystem variability off California. Glob. Change Biol. 19, 1662-1675. doi: $10.1111 /$ gcb. 12165

Sydeman, W. J., Thompson, S. A., García-Reyes, M., Kahru, M., Peterson, W. T., and Largier, J. L. (2014b). Multivariate ocean-climate indicators (MOCI) for the central California Current: environmental change, 1990-2010. Prog. Oceanogr. 120, 352-369. doi: 10.1016/j.pocean.2013.10.017

Timmermann, A., Oberhuber, J., Bacher, A., Esch, M., Latif, M., and Roeckner, E. (1999). Increased El Nino frequency in a climate model forced by future greenhouse warming. Nature 398, 694-696. doi: 10.1038/19505

Vander Woude, A. J., Largier, J. L., and Kudela, R. M. (2006). Nearshore retention of upwelled waters north and south of Point Reyes (northern California). Deep-Sea Res. Pt. II 53, 2985-2998. doi: 10.1016/j.dsr2.2006.07.003

Varela, R., Álvarez, I., Santos, F., deCastro, M., and Gomez-Gesteira, M. (2015). Has upwelling strengthened along worldwide coasts over 1982-2010? Sci. Rep. 5, 10016. doi: 10.1038/srep10016

Wang, D., Gouhier, T. C., Menge, B. A., and Ganguly, A. R. (2015). Intensification and spatial homogenization of coastal upwelling under climate change. Nature 518, 390-394. doi: 10.1038/nature14235

Winant, C. D., Dorman, C. E., Friehe, C. A., and Beardsley, R. C. (1988). The marine layer off Northern California-An example of supercritical channel flow. J. Atmospher. Sci. 45, 3588-3605.

Yáñez, E., Barbieri, M. A., Silva, C., Nieto, K., and Espíndola, F. (2001). Climate variability and pelagic fisheries in northern Chile. Prog. Oceanogr. 49, 581-596. doi: 10.1016/S0079-6611(01)00042-8

Conflict of Interest Statement: The authors declare that the research was conducted in the absence of any commercial or financial relationships that could be construed as a potential conflict of interest.

Copyright (C) 2015 García-Reyes, Sydeman, Schoeman, Rykaczewski, Black, Smit and Bograd. This is an open-access article distributed under the terms of the Creative Commons Attribution License (CC BY). The use, distribution or reproduction in other forums is permitted, provided the original author(s) or licensor are credited and that the original publication in this journal is cited, in accordance with accepted academic practice. No use, distribution or reproduction is permitted which does not comply with these terms. 